$\xi=-1$

\title{
How Significant Arabic Brand Name, Halal Logo and Manufacturer Country of Origin Image Trigger Consumer Purchase Decision on Halal Cosmetic
}

\author{
Telisiah Utami Putri \\ Doctor of Research in Management, BINUS University, \\ *Corresponding author E-mail: putri.telisiah@gmail.com
}

\begin{abstract}
Halal cosmetic is becoming a trend, not only directly targeted to muslim women as main consumer but non-muslim women also set as a target. Halal cosmetic is not only perceived as a product that meets islamic laws and proper to be used by muslim woman but more than that, it is perceived as a product that provides good quality assurance, does not contain with harmful substances, safe and ethical products. Some aspects from manufacturer side thought to have significant role as a trigger in purchase decision towards halal cosmetic. This study explores the variabels of Arabic brand name, halal logo and manufacturer country of origin image to be addressed deepen to check how those variabels influence consumer positive perception that lead to purchase decision on halal cosmetic.

This study is conducted via on-line survey by using WhatsApp mobile application in Surabaya. Respondents are women 20 - 50 years old, muslim and non-muslim, users of mass-market cosmetic brand in Indonesia

Collected answers from 76 respondents within one week field project. The result of this study is expected to be a preliminary study used by cosmetic manufacturer as a reference to set up the most suitable product strategy to be competitive in halal cosmetic market.
\end{abstract}

Keywords: Halal Logo, Manufacturer country of origin, Arabic brand name, purchase decision

\section{Introduction}

The world's Muslim population growth and increased revenue in Muslim majority countries that show a positive trend has brought a significant increase in demand for halal products globally. Global market demand for halal cosmetic products continue to rise, in 2015 the value of the global market for cosmetics women to reach US $\$ 23.4$ billion and is expected in 2020 will reach US $\$ 45$ billion with a CAGR of $14.3 \%$, while the growth of the cosmetics market in Asia-Pacific region will experience growth of $11.8 \%$ from the period 2013-2018(1)

The increasing demand for halal cosmetic also occur in nonmuslim western countries, along with increasing consumer awareness on halal cosmetics, cosmetic with halal assurance is identified as the product that is safe and having high quality assurance, because it does not contain elements that are harmful to the body, and free from the element of animal-derived.

Although muslim is the major population in Indonesia and contribute significant affect to halal cosmetic market in Indonesia, supported by research conducted by the Pew Research Centre "The Future of the Global Muslim Population" - January 2011 (2) estimates that by 2030 Indonesia will occupy the 2 nd position of the largest Muslim population in the world, numbers of 238 million people, in fact that does not mean halal cosmetics will be devoted only to Muslim women, in practice, non-Muslim women consumers also become the target consumers for cosmetic manufacturers. For halal cosmetics manufacturer itself non-Muslim consumers are their potential target consumer, by taking the nonmuslim consumers as target market besides muslim consumers, halal cosmetic market becomes wider and has more possibility to greater business opportunities.

Along with the consumer awareness of halal cosmetic known as safe for health, halal cosmetic perceived provide guarantees for the safety, purity and healthy can become its own attractiveness to non-muslim consumer in Indonesia. Halal is no longer just purely religious issue. It is in the realm of business and trade, and it is becoming a global symbol for quality assurance and lifestyle (3). With the increasing demand for halal cosmetic particularly in Indonesia market, trigger cosmetic manufacturers to adapt to these changes, trying to make dedicated halal cosmetic product or register their existing products to the formal institutions authorized to issue halal certification and obtain halal logo are some part of the ways to be taken.

This study started from the requirements of halal cosmetics manufacturer to find out How significant halal product attributes and manufacturer country of origin image trigger consumer purchase decision, halal product attributes are define for Arabic brand name and halal logo based on consideration that these aspects are quite familiar and have strong perception with halal image while manufacturer country of origin image is taken as an anwer for cosmetic industry.

This study has taken respondents of women from age range 20 up to 50 years old both are muslim and non-muslim in Surabaya, users of mass-market cosmetic brand, the survey conducted via on-line survey. The result of this study is expected to be a preliminary study used by cosmetic manufacturer to set up the most suitable product strategy to be competitive in halal cosmetic market. 


\section{Theoretical Framework}

This study uses Theory of reason action (4) The purpose of behavior is influenced some one's attitude toward the specific characteristics being considered and the subjective norm. Social pressure to perform the action. It consists of attitude, subjective norms, behavior.

Theory The behavioral plan became the theoretical foundation that later evolved into Theory of Plan Behavior (5)(6), the basis for the selection of Theory of plan behavior to support the decision to purchase halal cosmetics against other antecedents because the purchase decision in halal cosmetics is not included in impulse buying behavior, generally before purchasing cosmetics, consumers have first planned the choice of brand or type of cosmetic product they want to use or purchase.

The proposed framework for this research does not directly translate Theory of Plan Behavior, but Theory of Plan Behavior helps explain the way in which consumers have a belief or perception that is determined or influenced by the consumer's desire to engage in behavior or action, the most relevant component of the TPB is the attitude (Attitude).

The attitude that comes from belief (Belief) if halal cosmetics is better, in terms of the feelings of elements about halal cosmetics can provide positive emotions and thus create a feeling of security to the product and affect consumer behavior to the next stage which ultimately determines the decision to purchase halal cosmetics.

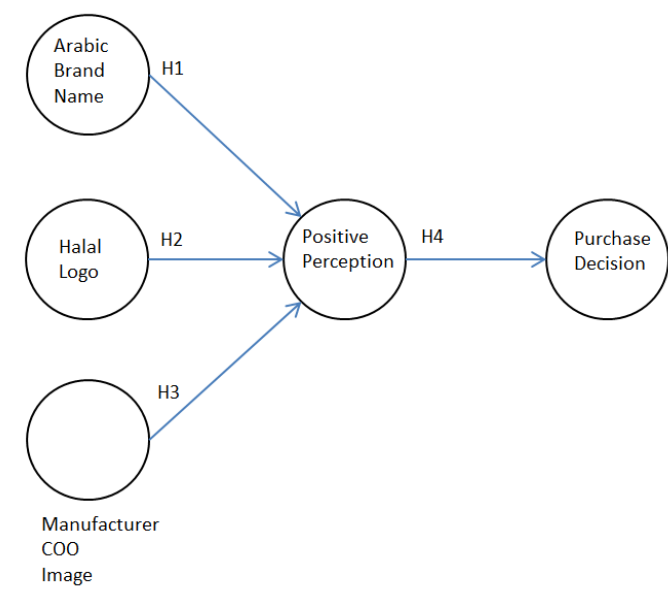

Figure 1: Research Model

\subsection{Arabic Brand Name}

As one of the variables that supposedly give effect in the perception of consumers to choose halal cosmetic, it is not inseparable from the condition that halal is directly related to Islam and Arabic terminology correlated strongly with Islam, so as to be seen whether Arabic terminology significantly becomes Influence factor in purchase intention towards halal cosmetic.

Based on (7) has recognized that certain brands may not only be represented by a name or a symbol, a brand perception and consumer sentiment towards products and services, which means consumer's point of view. Brands can affect preference and intention to buy consumer (8)(9). Naming the brand by using Islamic brand or Arabic terminology is interesting for further study, nowadays some cosmetic brands in Indonesia are named with Arabic brand name, this can be one of the taken action to create differentiation amongs other brands, naming the product with Arabic brand name supposedly provide assistance in delivering messages if the product is halal or in purpose for muslim.

Studies on the Arabic brand name are not much to be found, one can be used as a reference is (10) refer his journal in Banking Industry, based on his research findings most of the respondents agree that the Arabic terminology gives sort of competitive edge for the Islamic banks but at the same time they indicate that the catchy Arabic name will give them difficulty in gaining a fast information and comprehension towards the product, another reference comes from Miles Young speech (11) warns that Islamic branding can be seen "as something worthy but fundamentally second-rate". Having said that, the Noor Brand Index, a ranking of brands according to the perception of Sharia friendliness, classified two well-known multinational brands in the financial sector, namely, HSBC and RBS, as the worst perceived in terms of Sharia friendliness.

H1 : There is significant relationship between Arabic brand name and positive perception

\subsection{Halal Logo}

Having a Halal logo or certificate in today's globalized world is a must in order to cater for all Muslim needs(12). Based on (13) research finding in Malaysia, the positive correlation between labelling and purchase intention indicates that as customers have higher confident in labelling of the halal products, they will have higher intention to purchase the Halal products. Consumers who can differentiate and are confident about the genuineness of the Halal logo tend to have higher intent to purchase the products.

In Indonesia nowadays many cosmetics can be found with the halal logo, giving halal logo on cosmetics is not only apply to new brand, or brand with specific targeting to muslim consumer and claiming itself as halal cosmetic brand, but existing or even old cosmetic brands are started applying halal logo on their products, the authorized institution in Indonesia that have authorization to issue halal certification is only LPPOMMUI.

Manufactures' practice to apply halal logo on products do not necessary give them chance to the be chosen by target consumer, therefore halal logo becomes one of the variabels to be checked in this study, it is necessary to find out whether halal logo on product significantly influence consumers purchase intention towards halal cosmetic between muslim and non-muslim consumers.

In his study (14) said consumers assess product attributes as a basis for evaluating a product with respect to the benefits consumers seek when purchasing the product. Consumers also use attributes to make comparisons between competitive brands. The importance of attributes goes beyond the physical features of a product because, consumers most often attribute attributes to the consequences of purchasing or using the product.

Initially the researchers looked at attribute products as the physical properties of products measured quantitatively and objectively (15). However, in recent years it has extended its scope to all criteria that can be evaluated, including the objective or physical nature of price, brand name or subjective criteria such as quality, style, profit or value (16)(17). Islamic brand and halal logo are attributes on halal cosmetic product that will be assessed whether significant enough in building positive perception

$\mathrm{H} 2$ : There is significant relationship between halal logo and positive perception

\subsection{Manufacturer Country of Origin Image}

Such as brands, countries should also have equity associated with them (18). Consumers tend to embrace certain ideas and stereotypes of foreign countries as producers of goods and services and then use these ideas to evaluate the qualities of these products (19).

Manufacturer country of origin refer to the type of inferential belief (4), this type of belief is formed by making inferences (correctly or incorrectly) based on past experience as this experience relates to current stimulus, as an example a person whose experience suggests that German cars are durable might infer that since an Audi is a German car, an Audi is a durable car (20).

The same thing applies to cosmetics industry, especially halal cosmetics, to be associated perfectly as halal cosmetic products, 
the country where the halal cosmetic products manufactured become one of the associations forming towards image of the product. Accordingly, manufacturer should put on interest in understanding how country of origin associated with consumers' perception towards quality judgments and purchase decision.

The research area of manufacture of products and its effects on consumer preferences have long been discussed in the marketing and international business literature as "country-of-origin effects". Refer to (21) country of origin may be used as a stereotype measure that acts as an external product evaluation cue. (22) found that the cultural dimension of individualism and collectivism will influence the country-of-origin effects on product evaluation.

Country's image can be thought of as a proxy of overall attractiveness of a country's products, and governs a country's ability to produce globally competitive products and is an information cue that affects consumers' perceptions and mental representations of country-of-origin (23). country-of-origin image has a considerable impact on consumers' evaluation of products originating from different countries and therefore influences their subsequent buying decisions (21).

Variable manufacture of origin image is one of the important variabels to find out on creating positive perception that might trigger purchase decision on halal cosmetic since it is related directly to long-term corporate strategic decision.

H3 : There is significant relationship between manufacturer country of origin image and positive perception

\subsection{Positive Perception}

Positive perception begins with the collection of information from the environment. The information obtained is then interpreted by the consumer. This process of interpretation requires acceptance of information and includes two cognitive processes of attention and comprehension. In the consumer attention process choose which information is needed, then the consumer comprehension process determines the subjective meaning that creates knowledge and belief (beliefs). This knowledge and beliefs are stored in the memory and can be "called back" at any time in the future. At the integration stage, consumers combine the knowledge and feelings of the product or brand to create attitudes and intentions that are the trigger factors of a behavior. Consumers who have the same affiliation will share the same cognitive system(24).

Positive perception becomes the mediating variable between Arabic brand name, halal logo and manufacturer country of origin image with purchase decision in halal cosmetic.

$\mathrm{H} 4$ : There is significant relationship between positive perception and purchase decision

\subsection{Purchase Decision}

According to Kotler, Armstrong has four main factors that influence consumer buyer behavior (25) Consumer purchasing behavior is influenced by four main characteristics of buyers: cultural, social, personal, and psychological. While many of these factors can not be influenced by marketers, it can be useful for identifying interested buyers and in shaping products and appeal to better serve consumer needs.

Referring to the journal written by Lin (26) Consumer behavior and consumer purchase behavior in accordance with the confirmation of his request. Therefore, in this study the following two elements are used:

1. The purpose of information retrieval: summarizing consumer behavior and buying behavior based on references from (27) (28), when the consumer confirms his request, he will start looking for information relevant. That means consumers read about relevant product information through various sources, compare differences between products, and then spend more time on product searches (29). In this process when consumers buy a product, the intention of information retrieval takes a large portion. Therefore, the desire to search information as the first element in influencing consumer purchasing decisions.

2. Buying desire: in evaluating alternatives and decision-making decision maps, (30) suggest that between alternative evaluations and purchasing decisions, both will shape the desire to buy. (4) verify that buying desire can be considered an important index for predicting consumer behavior. Therefore, this study selects the buying desire as a second element influencing consumer purchasing decisions.

\section{Methodology}

The approach used is a quantitative model and this research was conducted via on-line survey, target respondents are women age range between $20-50$ years old who are familiar exposed to the Internet or web-based users, located in Surabaya.

This research model has five latent variables. The collection of data to see relationships between latent variables using a questionnaire five-point Likert scale where (1) for the selection of "Strongly Disagree" to (5) "Strongly Agree". As for the demographic questions using multiple choice. The indicator questions or variable measurements in this study was adapted from several sources.

Questionnaires distributed to 100 female respondents combined between muslim and non-muslim respondents with the criteria of the respondents as follows: they are in active age group 20 up to 50 years old, use or have ever used cosmetic brand regular product or mass-market brand, brand decision maker, SES and education levels are free (not restricted), questionnaires filled by respondents themselves (self-administered questionnaire) through on-line survey.

To determine the sample size for quantitative research, according to Robin Hill (31) in the journal titled "What Sample Size is "Enough" in Internet Survey Research?", he mentioned that according to (32) in behavioral research, sample larger than 30 is ensure the researcher the benefit of central limit theorem while a samples of 500 assure that sample error will not exceed $10 \%$ of standard deviation about $98 \%$ time. Thus the range of 30-500 for sample size is appropriate for a study. In this research, the respondent collected for quantitative research is 76 persons with simple random sampling as all kind of respondents, as long as they use mass-market cosmetic brands, they have equal opportunity to participate in this survey.

\section{Result and Findings}

This study has collected 76 respondents from total 100 target respondents, on-line survey was conducted by using structural questionnaire, up loaded digitally by using Google forms, that been delivered by using smartphone through WhatsApp mobile application within 2 weeks of field study.

All questionnaires were evaluated using a five-point likert scale, where higher score represent agreement, while lower score represent disagreement. Respondent's demographic's were analysed separately from the primary model.

From respondents profile it is revealed if respondents are mostly comes from young age generation ages range 20-30 years old, graduated from senior high school and muslim.

After first modification, all returned answers were analysed using SmartPLS 3.0 Software. The results of reliability and validity tests indicate several items with loading factors lower than 0.7 were removed, and the analysis was performed once again. The second analysis results revealed that the remaining item's outer loadings exceed 0.7 which indicates if indicator variabels are acceptable. According to (33) suggested value 0.70 and 0.9 should be desirable in advance stages of research. 
Results of the cronbach's $\alpha$ are also as expected. PLS-SEM prioritizes the indicators according to their individual reliability, and cronbach's $\alpha$ assumes that all indicators are equally reliable. According to (34) cronbach's $\alpha$ measures of reliability that ranges from 0 to 1 , with values of 0.6 to 0.7 deemed the lower limit of acceptability. In this findings shown that all latent variabels get cronbach's $\alpha>0.8$.

Looking at the average variance extracted (AVE), results of convergent validity for each latent variable are also greater than the acceptable threshold of 0.5 (35). As a parameter, this indicates that the degree to which measures of contructs that theoretically should be related, are in fact related.

Analysis of discriminat validity is used to measure the validity and reliability of the model, in this section it can be seen that the relationship between itself for each latent variable is stronger than its relationship with other latent variables, it indicates that the latent variable is strong enough with itself and the indicator is also supported.

Looking at this diagram, the coefficient of determination (R2) for Purchase Decision as the endogenous latent variable is 0.860 moderately explain $86 \%$ of the variance from endogenous positive perception, while R2 value for Positive Perception is 0.688 moderately explains $68 \%$ of the variance among 3 exogenous latent variabels : Arabic brand name, Halal logo, Manufacturer COO image.

Among 3 endegenous latent variables, path coefficient shown if manufacturer country of origin image has positive and more significant relationship to create positive perception with value of 0.553 , second place comes from halal cosmetic which also has positive relationship with slightly lower significant level to positive perception.

Endogenous Arabic brand name has negative relationship to positive perception and the value of -0.084 shown low significant relationship. Arabic brand name is very interesting to check further since all indicator has $>0.7$ outer loading which means acceptable to measure latent variable. The negative inner model loading - 0.084 indicates if path relation from Arabic brand name is the opposite pattern to positive perception, thus inversely positive perception is likely to correlate to Arabic brand name variable. As refer to (34). The mean profile illustrate the interpretation of signs whether it is positive or negative on the discriminant weights and loadings. The negative weights or loadings are for those variabels with the opposite pattern, thus the construct from Arabic brand name should be change to endogenous latent variable.

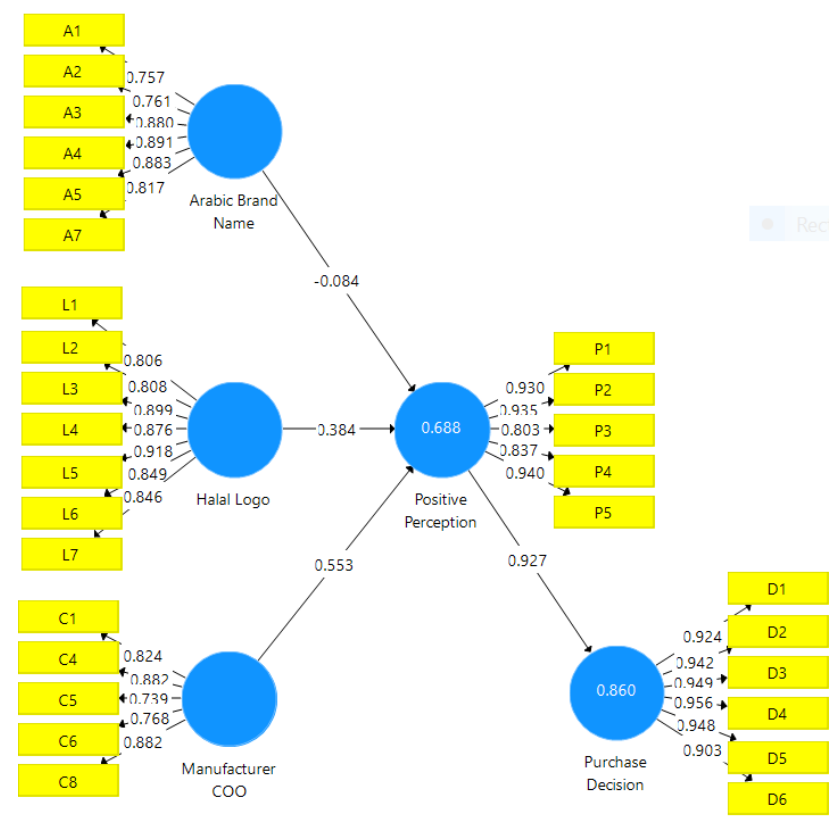

Figure1: Structural Graph After Data Processing Source: SmartPLS Software data processing
After re-run PLS after re-run the data processing and take another relation, it revelas if halal logo has positive and significant relatioship to Arabic name, however Arabic name although has positive relationship to purchase decision but the significance level is much lower than positive perception..

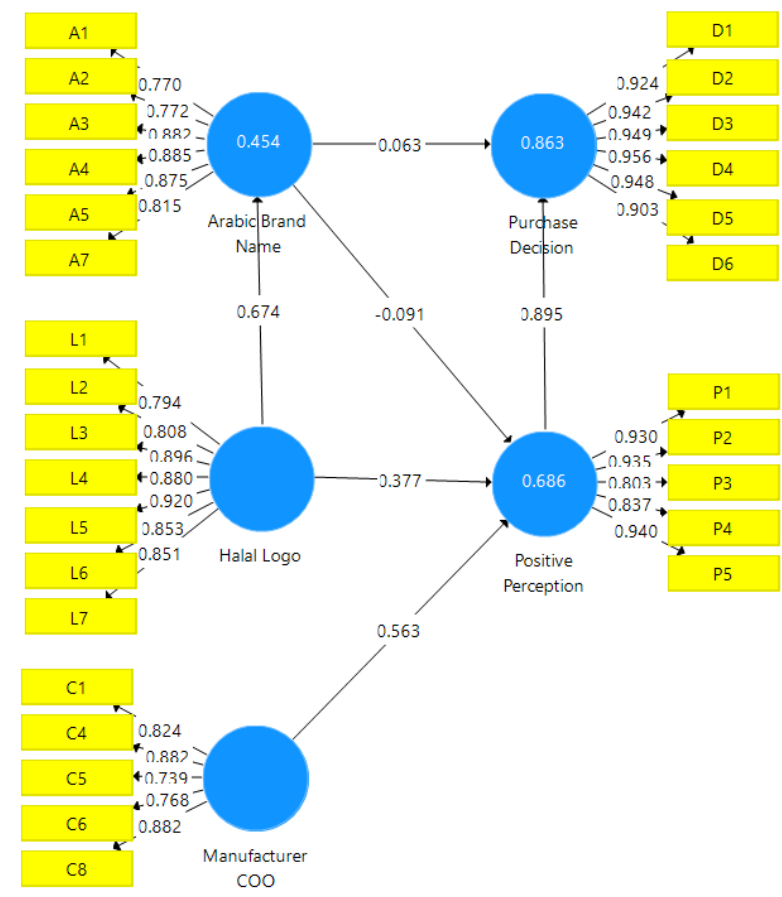

Figure2: Re-run Structural Graph

Source: SmartPLS Software data processing

\section{Conclusion}

The results of this indicate from 3 anticedents which predicted have significant relationship to purchase decision through mediating positive perception is manufacturer $\mathrm{COO}$ image, this finding can be used as a reference for halal cosmetic manufacturer in Indonesia to see if manufacturer $\mathrm{COO}$ image is significantly important to create consumer positive perception. based on (36)country of origin image creates extrinsic cue on brand evaluation relative to other extrinsic cues such as price, brand name, and service, and intrinsic cues such as reliability, safety, fuel efficiency, and styling, in this study manufacturer country of origin image relates to build up a certain association towards halal.

The COO image manufacturer's indicator in the study is the home country where halal cosmetic is produced, results of this study indicates if consumers are more confident if the products are made in Indonesia or Muslim countries, this finding is certainly useful for cosmetic manufacturers to set product strategy in order to meet their target consumer.

Halal logo is also considered positive and significant in creating positive perception, so it can be a complement from product attributes.

Arabic brand name although has positive relationship to purchase decision but the significance level is much lower than positive perception. While it also find out if Arabic brand name does not influence positive perception directly.

\section{References}

[1] Technavio. HALAL COSMETICS AND PERSONAL CARE MARKET IN THE APAC REGION 2014-2018 [Internet]. 2014 Available from: http://www.technavio.com/report/halal-cosmeticsand-personal-care-market-in-the-apac-region-2014-2018

[2] Pew Research Center. The future of the global Muslim population. Projections for 2010-2030. Popul Sp Place. 2011;13(1):1-221. 
[3] Lada S, Tanakinjal GH, Amin H. Predicting intention to choose $<$ IT $>$ halal $</$ IT $>$ products using theory of reasoned action. Int $\mathrm{J}$ Islam Middle East Financ Manag. 2009;2(1):66-76.

[4] Fishbein M, Ajzen I. Belief, Attitude, Intention, and Behavior: An Introduction to Theory and Research [Internet]. Reading, MA Addison-Wesley. 1975. p. 1-18. Available from: http://home.comcast.net/ icek.aizen/book/ch1.pdf

[5] Ajzen I, Madden TJ. Prediction of goal-directed behavior: Attitudes, intentions, and perceived behavioral control. J Exp Soc Psychol. 1986;22(5):453-74.

[6] Ajzen I. Ajzen, I. (1991). The theory of planned behavior. Organizational Behavior and Human Decision Processes.The theory of planned behavior. Vol. 50, Organizational Behavior and Human Decision Processes. 1991. p. 179-211.

[7] Kotler P, Armstrong G. Principles of Marketing [Internet]. Vol. 42, World Wide Web Internet And Web Information Systems. 2001. 785 p. Available from: http://www.amazon.com/dp/0139570020

[8] Alreck PL, Settle RB. Strategies for building consumer brand preference. J Prod Brand Manag. 1999;8:130-44.

[9] Ataman B, Ülengin B. A note on the effect of brand image on sales. J Prod Brand Manag. 2003;12(4):237-50.

[10] Muhamat AA, Jaafar MN, Azizan N binti A. An empirical study on banks' clients' sensitivity towards the adoption of Arabic terminology amongst Islamic banks. Int J Islam Middle East Financ Manag. 2011;4(4):343-54

[11] Muslim Futurism and Islamic Branding Speech by Miles Young at the Inaugural Oxford Global Islamic Branding and Marketing Forum, July 26. 2010;1-6.

[12] Abdul J, Shaari N, Shahira N. Dimension of Halal Purchase Intention : A Preliminary Study Shaari \& Arifin. Int Rev Bus Res Pap. 2010;6(4):444-56.

[13] Hussin SR, Hashim H, Yusof RN, Alias NN. Relationship between product factors, advertising, and purchase intention of Halal cosmetic. Pertanika J Soc Sci Humanit. 2013;21(SPEC. ISSUE):85-100.

[14] Akpoyomare OB, Patrick LPK, Ganiyu RA. The Influence of Product Attributes on Consumer Purchase Decision in the Nigerian Food and Beverages Industry: A Study of Lagos Metropolis. Am J Bus Manag. 2012;1(4):196-201

[15] Peterson P, Peterson D. University of Nebraska-Lincoln College of Business Administration. 2015;24(1):3-20.

[16] Grapentine T. Dimensions of an attribute. J Mark Res. 1995;7(3):18.

[17] Jamal A, Goode MMH. Consumers' product evaluation: a study of the primary evaluative criteria in the precious jewellery market in the UK. J Consum Behav [Internet]. 2001;1(2):140-55. Available from: http://dx.doi.org/10.1002/cb.61

[18] Maheswaran D, Chen CY. Nation Equity: Incidental Emotions in Country-of-Origin Effects. J Consum Res. 2006;33(3):370-6.

[19] Leclerc F, Schmitt B, Dubé L. Foreign Branding and its Effect on Product Perception and Attitudes. J Mark Res [Internet]. 1994;31(May):263-70. Available from: http://www.jstor.org/stable/1330431 ?origin=crossref

[20] Erickson GM, Johansson JK, Chao P. Image variables in multiattribute product evaluations: Country-of-origin effects. J Consum Res [Internet]. 1984;11(September):694-9. Available from http://www.jstor.org/stable/2488975

[21] Han MC. Country Image : Halo or Summary Construct? J Mark Res. 1989;26(2):222-30

[22] Gürhan-Canli Z, Maheswaran D. Cultural Variations in Country of Origin Effects. J Mark Res. 2000;37(3):309-17.

[23] Balabanis G, Diamantopoulos A. Domestic Country Bias, Countryof-Origin Effects, and Consumer Ethnocentrism: A Multidimensional Unfolding Approach. J Acad Mark Sci. 2004;32(1):80-95.

[24] Mokhlis S. The effect of religiosity on shopping orientation: An exploratory study in Malaysia. J Am Acad Bus. 2006;9(1):64-74.

[25] Philip Kotler GMA. Prentice Hall. Prentice Hall; 2005.

[26] Lin L, Chen C. The influence of the country-of-origin image , product knowledge and product involvement on consumer purchase decisions : an empirical study of insurance and catering services in Taiwan. 2006;

[27] Nicosia FM. Consumer Decision Process, Marketing and Advertising Implication,. Prentice-Hall, Englewood Cliffs, NJ, 1968. p. 156.

[28] Howard JA (1989). Consumer Behavior in Marketing Strategy. Prentice-Hall, Englewood Cliffs, NJ.; 1989

[29] McQuarrie, E.F. and Muson JM. "The Zaichkowsky personal involvement inventory: modification and extension", in Wallendorf,
M. and Anderson, P. (Eds), Advances in Consumer Research, Vol. 14, Association for Consumer Research, Provo, UT. 1992. pp 33-40.

[30] Kotler, P., Ang, S.H., Leong, S.M. and Tan C. A Marketing Management, Asian Perspective, 2nd ed. Prentice-Hall, Englewood Cliffs, NJ.; 1999.

[31] Hill R. WHAT SAMPLE SIZE is " ENOUGH" in INTERNET SURVEY RESEARCH? nterpersonal Comput Technol An Electron J 21st Century. 1998;6(3):1-10.

[32] John T. Roscoe. Fundamental Research Statistics for the Behavioral Sciences (International series in decision processes). 1979.

[33] Nunnally, J.C. \& B. Psychometric Theory. Vol. 3. McGraw Hill, New York; 1994.

[34] HAir Jr, Black, Babin A. Multivariate Data Analysis. Pearson/Prentice Hall; 2014.

[35] Bagozzi RP, Yi Y. On the Evaluation of Structural Equation Models. Vol. 16, Journal of the Academy of Marketing Science. 1988. p. 74-94

[36] Lee JK, Lee WN. Country-of-origin effects on consumer product evaluation and purchase intention: The role of objective versus subjective knowledge. J Int Consum Mark. 2009;21(2):137-51. 